\title{
Molecular and Biological Characterization of Lettuce mosaic virus (LMV) Isolates Reveals a Distinct and Widespread Type of Resistance-Breaking Isolate: LMV-Most
}

\author{
Renate Krause-Sakate, Olivier Le Gall, Hatem Fakhfakh, Martine Peypelut, Mohammed Marrakchi, \\ Christina Varveri, Marcelo A. Pavan, Sylvie Souche, Hervé Lot, F. Murilo Zerbini, and Thierry Candresse
}

\begin{abstract}
First, second, fourth, and eleventh authors: Equipe de Virologie, IBVM, INRA Bordeaux-Aquitaine, BP 81, 33883 Villenave d'Ornon Cedex, France; third and fifth authors: Laboratoire de Génétique Moléculaire, Immunologie et Biotechnologie, Faculté des Sciences de Tunis, Elmanar, 2092 Tunis, Tunisia; sixth author: Benaki Phytopathological Institute, Stephanou Delta Street 8, 14561 Kifissia, Greece; eighth and ninth authors: Pathologie Végétale, INRA, BP 94, 84143 Montfavet Cedex, France; seventh author: Departamento de Defesa Fitossanitária, UNESP/FCA, 18603-000, Botucatu, SP, Brazil; and first and tenth authors: Departamento de Fitopatologia/BIOAGRO, Universidade Federal de Viçosa, 36571-000, Viçosa, MG, Brazil.
\end{abstract}

Accepted for publication 28 January 2002.

\begin{abstract}
Krause-Sakate, R., Le Gall, O., Fakhfakh, H., Peypelut, M., Marrakchi, M., Varveri, C., Pavan, M. A., Souche, S., Lot, H., Zerbini, F. M., and Candresse, T. 2002. Molecular and biological characterization of Lettuce mosaic virus (LMV) isolates reveals a distinct and widespread type of resistance-breaking isolate: LMV-Most. Phytopathology 92:563-572.

Lettuce mosaic virus (LMV) causes an economically important seedborne and aphid-transmitted disease of lettuce and ornamental crops worldwide. The genetic diversity among 73 LMV isolates was examined based on a 216-nucleotide sequence at the variable region encoding the NIb-coat protein junction. Three clusters of LMV isolates were dis-

tinguished: LMV-Yar, LMV-Greek, and LMV-RoW. In the latter cluster, two subgroups of isolates, LMV-Common and LMV-Most, accounted for a large proportion of the LMV isolates analyzed. These two subgroups included the seedborne isolates, consistent with this property contributing a selective advantage and resulting in widespread distribution. In addition to being seedborne, LMV-Most isolates overcome the two resistance genes commonly used in lettuce, $\mathrm{mol}^{1}$ and $\mathrm{mol}^{2}$, and thus represent a potential threat to lettuce cultivation. The complete sequence of an LMVMost isolate (LMV-AF199) was determined, allowing a better definition of the genetic relationships among LMV-Most, LMV-Common, and an additional isolate of the LMV-RoW cluster.
\end{abstract}

Lettuce mosaic virus (LMV) is the causal agent of lettuce mosaic, the most devastating viral disease of lettuce (Lactuca sativa) worldwide (8). LMV belongs to the genus Potyvirus, within the family Potyviridae (3). The genomic organization of LMV is typical of potyviruses, with a single positive-sense genomic RNA of 10,080 nucleotides encapsidated as flexuous rods. The viral RNA encodes a single polyprotein of 3,255 amino acids, which is processed by three virus-encoded proteinases to yield mature viral proteins (23). The genomic RNA of potyviruses is covalently linked at its $5^{\prime}$ end to a virus-encoded protein (VPg) and is polyadenylated at its $3^{\prime}$ end (28). LMV is transmitted by aphids in a noncirculative manner, and is seedborne in lettuce $(8,25)$.

The control of lettuce mosaic in the field relies chiefly on exclusion of seedborne virus in commercial seed lots (31) and deployment of genetic resistance $(8,24)$. Genetic resistance is based almost exclusively on the use of either one of two recessive, probably allelic genes, $\mathrm{mol}^{1}$ (formerly named $\mathrm{g}$ ) and $\mathrm{mol}^{2}$ (formerly named $m o)(2,8,20,24,33)$. Levels of resistance conferred by these two genes can be either low (systemic virus accumulation but no symptoms, sometimes referred to as tolerance) or high (no systemic virus multiplication), and this may depend on the virus isolate $(20,21)$. Each of these genes may confer low-level resistance against some LMV isolates and high-level resistance against others (21). Most field isolates of LMV are seedborne in suscep-

Corresponding author: O. Le Gall; E-mail address: legall@bordeaux.inra.fr

Publication no. P-2002-0322-02R

(C) 2002 The American Phytopathological Society tible lettuce cultivars, but not in resistant cultivars carrying $m o 1^{1}$ or $m o l^{2}$, even in cultivars with low levels of resistance $(8,20)$. Therefore, in addition to a reduction of viral infection or symptom expression, the $\mathrm{mol}^{1}$ and $\mathrm{mol}^{2}$ genes also provide a reduction in the dissemination of LMV through seed. For simplicity, only the term resistance will be used henceforth to refer to the complex set of phenotypes associated with the $m o l^{1}$ and $m o l^{2}$ genes.

The combined use of genetic resistance and seeds tested to be free of LMV generally allows for adequate control of lettuce mosaic in the field (33). However, LMV isolates able to break the resistance afforded by $m o l^{1}$ or $m o l^{2}$ have been described $(8,15$, 20,21,29). Generally, resistance-breaking isolates are not seedborne, limiting their economic significance to local outbreaks. Some LMV isolates, however, combine resistance-breaking and seed-transmission properties, and are thus a major concern to lettuce growers worldwide $(8,15,21,29)$.

In a previous study, we described the relationships among biological and molecular properties of 10 selected LMV isolates, including two with seed transmission and resistance-breaking capabilities (21). The analysis of three separate regions of the LMV genome did not establish a correlation between the position of a given isolate in a dendrogram and its biological traits. These results suggested that the evolution of biological properties was not correlated with the evolution of the major molecular clusters of LMV as revealed by this analysis. Sequence-based clustering permits the identification of groups of isolates sharing a common evolutionary history and, perhaps, common biological properties. The establishment of such correlations may require analysis of a broader set of isolates than analyzed previously, and a region of the genome that provides an accurate description of the viral population. 
Our previous work (21) showed that the three widely spaced genomic regions analyzed yielded similar clusterings, which suggested the absence of recombination among these isolates. Therefore, analysis of one of these regions was considered sufficient to describe the LMV population. These results also showed that the region encoding the $\mathrm{C}$ terminus of the $\mathrm{NIb}$ and the $\mathrm{N}$ terminus of the coat protein $(\mathrm{CP})$ was most variable and the best marker of molecular clustering. In the present study, we extended our isolate database and focused on the NIb-CP junction region in order to obtain a more accurate view of the relationships between genetic affinities and biological properties of LMV isolates.

\section{MATERIALS AND METHODS}

Virus isolates. In addition to the 10 reference isolates previously described (21), LMV isolates were provided by colleagues or collected from the field in recent years from various regions of the world (Table 1). Isolates were also recovered from seed lots, provided by various seed companies, that tested positive for LMV. These isolates were retrieved by assaying four separate lots of 500 seeds each in inoculation buffer (21) and rub-inoculating susceptible or mol-containing lettuce plants (cvs. Trocadéro or Mantilia, respectively). All isolates were routinely propagated in plants of susceptible lettuce cv. Trocadéro in a greenhouse ( $16 \mathrm{~h}$ day length, 20 to $\left.30^{\circ} \mathrm{C}\right)$. When needed, isolates were stored at $+4^{\circ} \mathrm{C}$ as desiccated infected tissue (5).

Immunoprinting. A first evaluation of field-collected plant samples was performed by immunodetection of the LMV CP in tissue prints performed on nitrocellulose membranes (BA85, Schleicher \& Schull, Dassel, Germany). The first steps of this technique were more amenable to field conditions than other immunological assays and, in addition, its format allowed the easy testing of numerous samples simultaneously on the same membrane. Briefly, leaves were cut across the midrib, pressed on a paper towel to eliminate excess latex exuding from the cut, and firmly applied onto the membrane for several seconds. The membrane was air dried and directly processed, but could be stored at room temperature for up to several months without apparent loss of reactivity. The membrane was saturated for $30 \mathrm{~min}$ at room temperature in a $1 \%$ gelatin (ICN Biochemicals, Costa Mesa, CA) solution in blocking buffer $(10 \mathrm{mM}$ Tris- $\mathrm{HCl}, \mathrm{pH} 7.5$, and $350 \mathrm{mM} \mathrm{NaCl}$ ) and incubated for 1 to $2 \mathrm{~h}$ in radioimmunoassay buffer (10 mM Tris-HCl, pH 7.5, $160 \mathrm{mM} \mathrm{NaCl}, 0.1 \%$, wt/vol, sodium dodecyl sulfate, and $1 \%$, vol/vol, Triton X-100) containing a 1:1,000 dilution of rabbit immunoglobins raised against purified LMV virions and conjugated with alkaline phosphatase. After thorough rinsing, the membrane was placed in phosphatase buffer (100 mM Tris-HCl, pH 9.5, $100 \mathrm{mM} \mathrm{NaCl}$, and $5 \mathrm{mM} \mathrm{MgCl}_{2}$ ) containing $187.5 \mu \mathrm{g}$ of nitroblue tetrazolium chloride per $\mathrm{ml}$ and $94 \mu \mathrm{g}$ of 5-bromo-4-chloro-3-indolyl phosphate per ml. The reaction was stopped by extensive rinsing in water when, after about 5 to $15 \mathrm{~min}$, color development was evident for the infected samples used as positive controls. Under these conditions, the negative samples and controls showed no trace of staining. Samples were scored visually with a binocular microscope at low magnification.

Biological tests. Ability of the isolates to overcome the mol genes was evaluated after rub-inoculating two to three plants of cultivars carrying $\mathrm{mol}^{1}$ ('Mantilia' and 'Floribibb') or $\mathrm{mol}^{2}$ ('Vanguard 75' and 'Salinas 88'), and scoring of disease symptoms after 2 to 4 weeks. For each isolate, seed transmission was evaluated using enzyme-linked immunosorbent assay (ELISA) $(7,9,32)$ by testing at least 25 batches of 200 seeds collected from infected lettuce plants (cv. Trocadéro or early flowering line $8720 \mathrm{M}$, provided by E. Ryder). Isolates that had been recovered from contaminated seed batches of resistant cultivars were considered resistance-breaking without further testing.

Reverse transcription and polymerase chain reaction amplifications. Coupled reverse transcription and polymerase chain reactions (RT-PCR) were performed essentially as described (22), starting from semipurified total nucleic acids (4) and using the primers NIb and $\mathrm{P} 4$ or $\mathrm{P} 4 \mathrm{Gr}$ (22), with an annealing temperature of $56^{\circ} \mathrm{C}$ and an elongation time of $20 \mathrm{~s}$. The resulting amplified fragment extended from positions 8894 to 9171 in LMV-0 (GenBank Accession No. X97704, coordinates of which were used throughout for nucleotide or amino acid sequence positions unless otherwise stated) and was 278 nucleotides for this isolate.

Complementary DNA cloning. Total RNA was prepared from infected plants as described (4), and $5 \mu \mathrm{l}$ was used as template for an RT reaction primed with oligo(dT) using Avian myeloblastosis virus reverse transcriptase (Amersham Pharmacia Biotech, Upsalla, Sweden). The reaction was incubated at $42^{\circ} \mathrm{C}$ for $1 \mathrm{~h}$. PCR amplifications were performed using cDNA aliquots with various combinations of primers based on genomic sequences of LMV-0 or LMV-E (23). PCR reactions $(100 \mu \mathrm{l})$ contained $1 \mu \mathrm{l}$ of template cDNA, 100 pmol each primer, $0.25 \mathrm{mM}$ each dNTP, and 1 unit of Pfu DNA polymerase (Stratagene, La Jolla, CA). PCR consisted of 40 cycles of denaturation $\left(2 \mathrm{~min}, 94^{\circ} \mathrm{C}\right)$, primer annealing $\left(50 \mathrm{~s}, 50^{\circ} \mathrm{C}\right)$, and extension $(2 \mathrm{~min}$ per $\mathrm{kb}$ of amplified sequence, $72^{\circ} \mathrm{C}$ ). When necessary, PCR products were inserted in the cloning vectors pZErO-Kan (Invitrogen, San Diego, CA) or pGEM-T easy (Promega, Madison, WI).

Sequence determination and analysis. Nucleotide sequences were determined using primer $\mathrm{NIb}$ (and in some cases $\mathrm{P} 4$ or $\mathrm{P} 4 \mathrm{Gr}$ to resolve local ambiguities by sequencing the other strand of the RT-PCR product) and an automated sequencer (ABI-Prism 377; Perkin-Elmer, Boston, MA). The NIb-P4 RT-PCR products were not cloned before sequencing to provide an image of sequence mixtures possibly occurring within a particular isolate. The sequence from positions 8936 to 9151 (216 nucleotides) was routinely obtained from the NIb priming events and used for further analysis. Nucleotide or deduced amino acid sequences were aligned using ClustalX $(13,30)$. Neighbor-joining dendrograms (26) were calculated by ClustalX and displayed with TreeView (18). One thousand bootstrap replicates (12) were performed using the corresponding option of ClustalX to establish support values of each node in the dendrogram. The pairwise genetic distances between sequences were determined using the Kimura parameters (14), and averaged for given groups of isolates as required. Maximum likelihood (10) and parsimony (11) analysis of the multiple alignment were also performed using programs DNAML and DNAPARS from the Phylip 3.5 package (J. Felsentein, Department of Genetics, University of Washington, Seattle).

Homologous sequences from four other potyvirus species were also compared. For each species, five sequences representative of the principal known intraspecific clusters were chosen. The viruses analyzed were Plum pox virus (PPV), Pea seed-borne mosaic virus (PSbMV), Papaya ringspot virus (PRSV), and Potato virus $Y$ (PVY). The GenBank accession numbers of these sequences are (for each virus, the nucleotide coordinates of the region analyzed are given for one complete sequence, and homologous regions were used for the four other complete or partial accessions): PPV (X16415; positions 8487 to 8843-, X97398, D13751, S57405, and X56258), PSbMV (NC_001671; positions 8790 to 9043-, AJ252242, X89997, Z48509, and Z48508), PRSV (X67673; positions 9116 to 9406-, AB044342, AF120270, X78557, and D00594), and PVY (X97895; positions 8476 to 8667-, M11598, U09509, U06789, and AJ223593).

The sequences of cloned partial cDNAs obtained by RT-PCR using Pfu DNA polymerase (described previously) were determined and assembled to produce the full-length sequence of isolate LMV-AF199. Each nucleotide position was determined on both strands from two independently cloned cDNA, and confirmed by direct sequencing of RT-PCR products. The sequence identity between LMV-AF199 and LMV-0 or LMV-E was calculated at each position of the full-length sequence in a window of 150 nucleotides or 50 amino acids. 
TABLE 1. Isolates analyzed during the course of this work ${ }^{\mathrm{a}}$

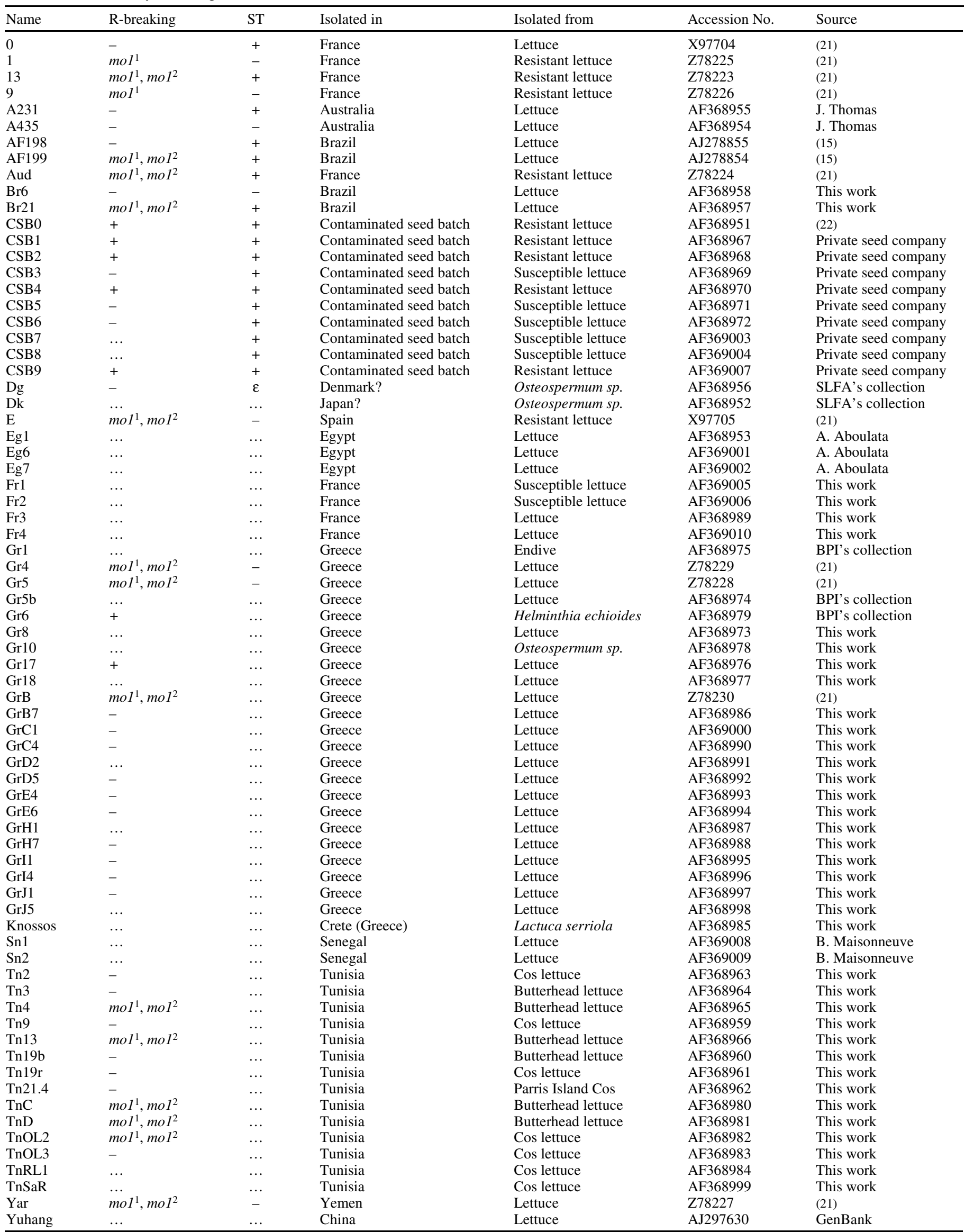

a The name of each isolate, its ability to overcome the resistance afforded by $m o l^{1}$ only $\left(m o l^{1}\right), m o l^{1}$ and $m o l^{2}\left(m o l^{1}, m o l^{2}\right), m o l^{1}$ without information on the ability to break $\mathrm{mol}^{2}(+)$, or none of these genes $(-)$, its seed transmission (ST: -, not detectable; +, seedborne; $\varepsilon$, poorly seedborne), its country and host of origin, the GenBank accession number of its relevant sequence, and its source are given in the respective columns. ... indicates no data available. The geographical origin of the isolates provided as Lettuce mosaic virus-infected seed batches was considered uncertain and thus not indicated. 
The algorithm developed in VTDIST2 (27) was used to detect possible recombination among full-length LMV sequence and between these and outer sequences. Briefly, this algorithm calculates a parameter named SSCF (sum of the squares for condensed fragments) within the actual set of aligned sequences and compares it with the average and standard deviation of SSCF values obtained from 10,000 random alignments derived from the original one, thereby evaluating the probability for the actual sequence set to have evolved without internal (inner SSCF) or external (outer SSCF) recombination.

\section{RESULTS}

Origin and biological properties of LMV isolates. Field LMV isolates were collected from Brazil, France, Greece, Senegal, and Tunisia. These were mostly from diseased lettuce plants, although some were also isolated from weeds or ornamental Asteraceae (Table 1). Tissue immunoblotting or ELISA revealed the presence of LMV in most of the plants with mosaic analyzed from each country, except Brazil (São Paulo state) where many lettuce plants with mosaic appeared to be free of LMV (data not shown). In Greece, LMV-infected samples were collected from lettuce, but one isolate (LMV-Gr10) was collected from ornamental Osteospermum sp. displaying mosaic and chlorotic spots on the leaves (but no symptoms on flowers). Additional LMV isolates from lettuce were obtained from collections kept in Australia, Brazil, Egypt, and Greece and also from Helminthia echioides in Greece (16) and Osteospermum spp. in Denmark and Japan (Table 1). LMV also was recovered from contaminated lettuce seed batches provided by various seed companies.

These LMV isolates can be placed into five groups based on their resistance-breaking and seed-transmission properties (Table 1): (i) not seedborne and with no ability to overcome any mol allele, (ii) not seedborne but with ability to break $\mathrm{mol}^{1}$ alone, (iii) not seedborne but with the ability to break both $m o l^{1}$ and $m o l^{2}$, (iv) seedborne and with no ability to overcome any mol allele, and (v) seedborne and able to break both $\mathrm{mol}^{1}$ and $\mathrm{mol}^{2}$. The ability to overcome resistance provided by the dominant gene Mo2 (20) was not evaluated during the course of this study.

Molecular characterization of the LMV isolates. Nucleotide and amino acid sequences of the PCR-amplified DNA fragment between nucleotide positions 8936 and 9151 of 73 LMV isolates were compared. All the isolates analyzed had the same number of nucleotides and predicted amino acids in this region, except for LMV-GrH1 which lacked one codon (positions 9011 to 9013), resulting in the deletion of one of the four repeated aspartates $\left(\mathrm{DEDDDD}_{2965-2970}\right.$ ) located near the $\mathrm{C}$ terminus of the $\mathrm{NIb}$ protein.

The amino acid sequence DEVYHQ/V $2972-2978$ located at the NIb-CP cleavage site was strictly conserved among almost all isolates tested (Fig. 1). However, LMV-A435 had a glycine instead of a valine at position 2978, as described for LMV-Romaine (34),

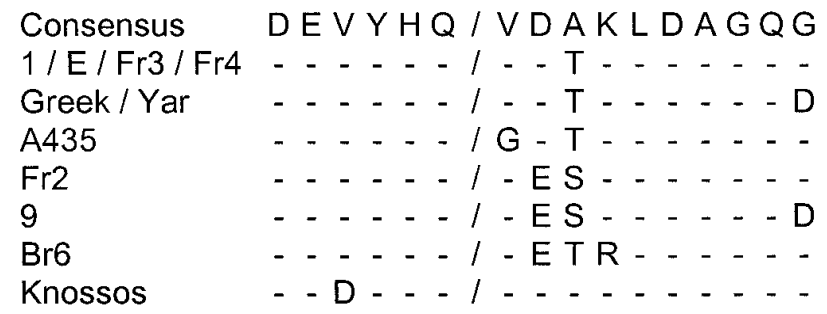

Fig. 1. Amino acid sequence alignment around the cleavage site between the $\mathrm{NIb}$ and coat protein (CP) coding regions of 73 Lettuce mosaic virus isolates (positions 2972 to 2987). The consensus line shows the sequence conserved in 52 of the 73 isolates analyzed. Greek stands for isolates Gr1, Gr4, Gr5, Gr5b, Gr6, Gr8, Gr10, Gr17, Gr18, and GrB. The oblique bar represents the cleavage site between NIb and CP. and LMV-Knossos had an aspartate instead of valine at position 2974. All sequences analyzed contained the Asp-Ala-Gly triplet involved in aphid transmission in other potyviruses (1), preceded by a leucine and followed by a glutamine (Fig. 1).

A total of 119 nucleotides (out of 216) and 45 amino acids (out of 72) were polymorphic among these LMV isolates. Dendrograms reflecting the molecular affinities between these LMV isolates were constructed from nucleotide (Fig. 2) or amino acid (Fig. 3) sequence alignments. Nucleotide and amino acid sequence analyses defined the same three main clusters containing 1, 10, and 62 isolates, respectively. These clusters were supported by 99 to $100 \%$ bootstrap values (Figs. 2 and 3). This organization of LMV isolates into three clusters has been described previously for a more restricted set of isolates, based on this same region and on two other regions of the viral genome (21).

One cluster is represented by the single isolate LMV-Yar. The second cluster includes 10 isolates from Greece and was therefore named Greek. There was no isolate of non-Greek geographical origin in the Greek cluster. However, this cluster did not contain all isolates from Greece. Pairwise nucleotide sequence divergence was evaluated between all pairs of LMV isolates using Kimura's parameters (14), and average divergence was established within and between the groups described above. The average pairwise nucleotide sequence divergence among isolates of the Greek cluster was $0.0734 \pm 0.0640$ substitutions per site (sps), with LMV-Gr17 being the most divergent $(0.1482 \pm 0.0071$ sps with the other nine Greek cluster isolates). On average, the Greek cluster nucleotide sequences differed from LMV-Yar by $0.3389 \pm$ 0.0070 sps. The third cluster, named RoW (rest of the world), included most of the LMV isolates, representing very different geographical origins. Isolates from Greece and Middle Eastern countries were also found in this cluster. Average divergence within this group was $0.0750 \pm 0.0437 \mathrm{sps}$ and, on average, the RoW nucleotide sequences differed from LMV-Yar by $0.2888 \pm$ $0.0139 \mathrm{sps}$, and from the Greek cluster isolates by $0.3576 \pm$ 0.0179 sps. The average divergence observed for interspecific comparisons of the same genomic region (Table 2) ranged from $1.154 \pm 0.089 \mathrm{sps}$ (LMV versus PVY) to $4.845 \pm 0.778 \mathrm{sps}$ (PVY versus PPV), considerably higher than between the most distant LMV sequences. This suggests that even the most distantly related isolates described in this study belong to the species LMV.

Within the RoW cluster, 11 sequences (Eg1, Eg6, Eg7, 1, E, Fr3, Br6, A435, Fr4, 9, and Fr2), some of them organized in subclusters supported by representative bootstrap values, branched at about $0.05 \mathrm{sps}$ from the top of the branches and formed five branches of one to three sequences. Three Egyptian isolates (Eg1, $\mathrm{Eg} 6$, and $\mathrm{Eg} 7$ ), closely related to each other in sequence, were the most divergent of the entire RoW cluster. A second group (labeled LMV-Common in Figure 2 for reasons developed below), containing 37 sequences including LMV-0 (21) and LMV-AF198 (15), was supported by a $92 \%$ bootstrap value in the dendrogram derived from nucleotide sequences (Fig. 2). The sequences within the group LMV-Common differed from each other by $0.0197 \pm$ $0.0088 \mathrm{sps}$ on average. Isolate TnOL2 was placed outside of this group, and its exclusion was supported by a significant bootstrap value. A group of 13 sequences (labeled LMV-Most in Figure 2 for reasons developed below), supported by a $100 \%$ bootstrap value, showed very little sequence variation (1 nucleotide difference from the consensus in four isolates, none of which were at the same position). The group LMV-Most includes the isolates LMV-13 (21), LMV-Aud (21), LMV-CSB0 (an isolate from a seed lot obtained in Chile, briefly mentioned in literature citation 22), and LMV-AF199 (15). Both LMV-Common and LMV-Most include isolates from a diversity of geographical origins.

The dendrograms obtained from the same multiple nucleotide sequence alignment using two other types of algorithms, parsimony and maximum likelihood, had similar topologies for the 
nodes that were supported by bootstrap values higher than $50 \%$ (data not shown).

At the amino acid level, the topology of the RoW cluster is essentially similar to that of the dendrogram derived from nucleotide sequences, with some notable exceptions (Fig. 3). The most striking differences are the split of the group LMV-Common into two subgroups, and the closer distance between the groups LMV-
Most, LMV-TnOL2, and the three Egyptian isolates (Eg1, Eg6, and Eg7). However, the amino acid-based dendrogram is supported by only few amino acid differences in the LMV-Common/ LMV-Most branch. For instance, only 3 of 72 amino acids differentiated LMV-0 and LMV-AF199, and 1 of 72 differentiated LMV-0 and LMV-Yuhang. Surprisingly, most of these amino acid differences were in NIb rather than in the hypervariable $\mathrm{CP} N$

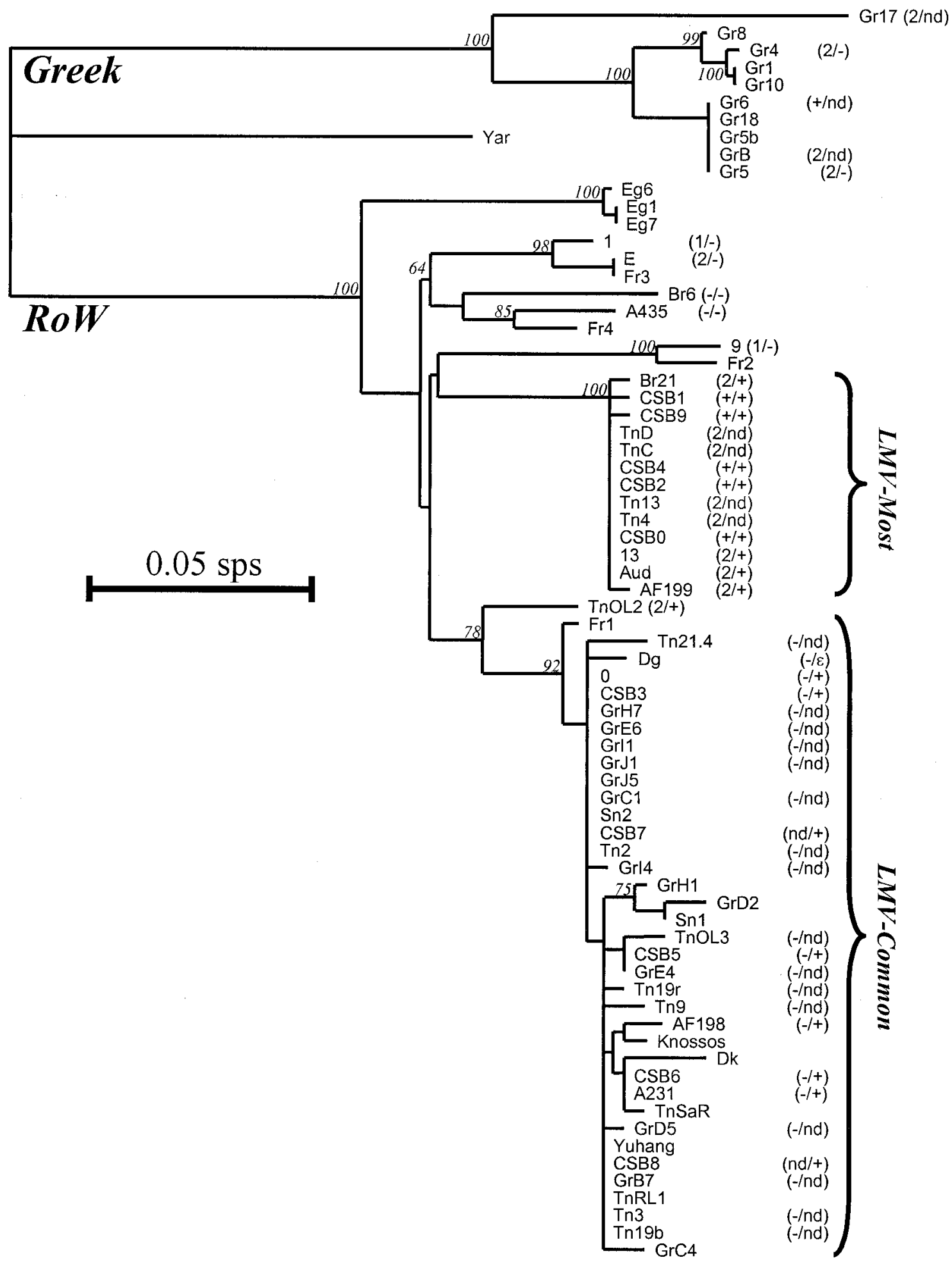

Fig. 2. Dendrogram showing the levels of sequence divergence between Lettuce mosaic virus (LMV) isolates using nucleotide sequences. The bars represent a distance of 0.05 substitutions per site (14). The level of support of each node was evaluated as the percentage of 1,000 bootstrap replicates, and is indicated for the nodes for which it is higher than $60 \%$. The resistance-breaking (-, does not overcome $m o 1^{1}$ or $m o l^{2} ; 1$, overcomes $m o 1^{1}$ but not $m o 1^{2} ; 2$, overcomes both $\mathrm{mol}^{1}$ and $\mathrm{mol}^{2}$; +, overcomes $\mathrm{mol}^{1}$ but $\mathrm{mol}^{2}$-breaking not tested; nd, not determined) and seed transmission (-, not seedborne; +, seedborne; nd, not determined) of each isolate for which at least one of them have been determined and are indicated in brackets. 
terminus ( 1 of 39 amino acid differences in the $\mathrm{CP} N$ terminus of LMV-0 and LMV-AF199).

Correlation between biological and molecular properties. Isolates capable of overcoming $\mathrm{mol}^{1}$ or $\mathrm{mol}^{2}$ were found in each of the three clusters: Yemen (LMV-Yar), Greek, and RoW (Table 1; Fig. 2). Within the RoW cluster, all isolates belonging to the group LMV-Common did not overcome resistance. In contrast, all of the isolates in the group LMV-Most induced symptoms on lettuce cultivars containing $\mathrm{mol}^{1}$ or $\mathrm{mol}^{2}$. Isolates outside of these two groups had various types of resistance-breaking capabilities (Table 1; Fig. 2).

LMV-Yar, as well as those isolates tested in the Greek cluster, were not seedborne (Table 1; Fig. 2). Seed transmission of the RoW isolates differed. Isolates from the groups LMV-Common and LMV-Most were seedborne although some, such as LMV-Dg, were transmitted only at a low efficiency (data not shown). In

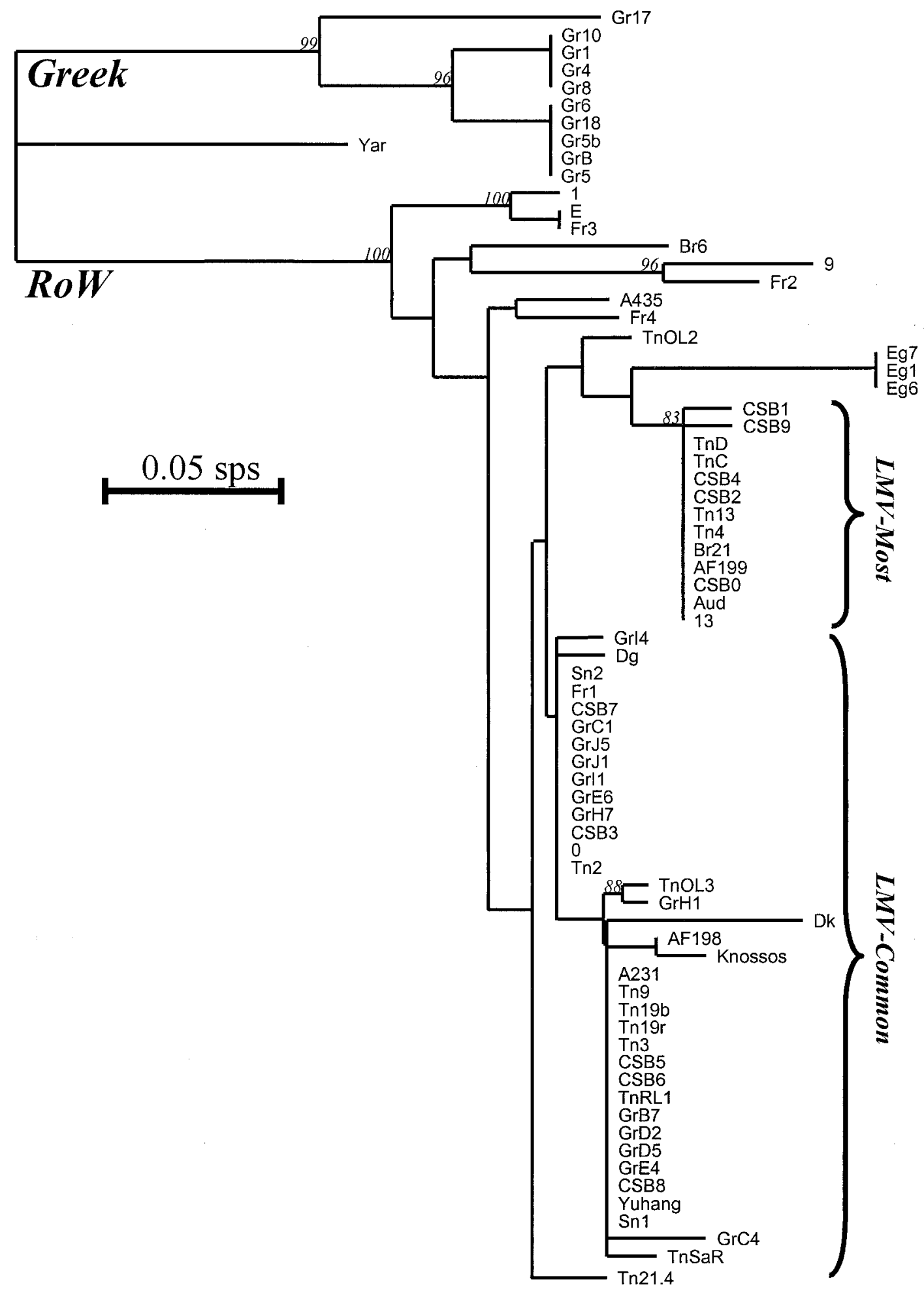

Fig. 3. Dendrogram showing the levels of sequence divergence between Lettuce mosaic virus (LMV) isolates using deduced amino acid sequences. The bars represent a distance of 0.05 substitutions per site (14). The level of support of each node was evaluated as the percentage of 1,000 bootstrap replicates, and is indicated for the nodes for which it is higher than $60 \%$. The resistance-breaking (-, does not overcome $\mathrm{mol}^{1}$ or $\mathrm{mol}^{2} ; 1$, overcomes $m o 1^{1}$ but not $\mathrm{mol}^{2} ; 2$, overcomes both $m o 1^{1}$ and $\mathrm{mol}^{2}$; +, overcomes $\mathrm{mol}^{1}$ but $\mathrm{mol}^{2}$-breaking not tested; nd, not determined) and seed transmission (-, not seedborne; +, seedborne; nd, not determined) of each isolate for which at least one of them have been determined and are indicated in brackets. 
contrast, none of the tested RoW isolates outside of these two groups was seedborne (Table 1; Fig. 2).

Because the group of 37 isolates includes most field isolates including some of the oldest known, it was named LMVCommon. LMV-Common isolates are seedborne and, usually, efficiently controlled by the genes $m o l^{1}$ and/or $m o l^{2}$. The group of 13 sequences, corresponding to seedborne isolates capable of overcoming both $\mathrm{mol}^{1}$ and $\mathrm{mol}^{2}$, was named LMV-Most (for mol-breaking, seed-transmitted).

The genomic region analyzed by Zerbini et al. (34) for a set of 10 field isolates from California and of a reference isolate from France, LMV-P, overlaps only partially with the region analyzed in this study $(21,34)$. These sequences were nevertheless compared with those described in this study in the overlapping 92 nucleotide region (positions 9060 to 9151). Sixty-five nucleotides were polymorphic in this set of 84 sequences. The general topology of the dendrogram resulting from analysis of this smaller region was essentially similar to that shown in Figure 2 (data not shown). Based on this limited region, all 10 Californian isolates and LMV-P clustered within LMV-Common, except for LMVRomaine. This isolate, one of five of the so-called Firestone strain collected in the Salinas Valley (34), was placed in a new branch rooted within the RoW cluster but distinct from LMV-Common and LMV-Most (data not shown).

Complete nucleotide sequencing of LMV-AF199. The complete nucleotide sequence of the genome of an LMV-Most isolate, LMV-AF199, was determined (GenBank Accession No. AJ278854) and compared with those of two other types of LMV-RoW, LMVCommon (isolate LMV-0), and one of the more divergent RoW isolates (isolate LMV-E) (23).

The LMV-AF199 nucleotide sequence differs from those of LMV-0 and LMV-E only by point mutations, with no deletion or insertions. The AF199 genomic RNA contains 10,080 nucleotides with a single open reading frame capable of encoding a 3,255amino acid polyprotein (Fig. 4). The nucleotide sequence of LMVAF199 is $95.9 \%$ (415 differences) and 93.9\% (613 differences) identical to those of LMV-0 and LMV-E, respectively. The amino acid sequence of the LMV-AF199 polyprotein is $98.0 \%$ (65 differences) and $96.7 \%$ (108 differences) identical to those of LMV-0 and LMV-E, respectively. The sequence divergence rate between LMV-AF199 and LMV-0 or LMV-E shows local variation, but in general is roughly constant along the entire viral genome at the nucleotide level (Fig. 4A). This was also the case for LMV-0 and LMV-E (23) and suggests the absence of detectable recombination events in the history of these three LMV isolates, which would have led to large-scale variations in the divergence rates $(6,17)$. This observation was statistically confirmed because VTDIST2 did not detect recombination at a significant confidence level $(P=$ $26.1 \%$ for the absence of recombination among LMV-0, LMV-E, and LMV-AF199; $P=28.1 \%$ between any of these and outer sequences).

The comparison between amino acid sequences of LMV-AF199 and LMV-0 or LMV-E showed regions of higher-than-average divergence (Fig. 4C), as was also found for LMV-0 and LMV-E (23). The largest of these regions corresponds to the entire P1 protein. Another variable region is located in the middle of the polyprotein, at the $\mathrm{C}$ terminus of the CI protein, and within the VPg region. The higher level of divergence between LMV-AF199 and LMV-E compared with LMV-0 is due to the presence of specific regions that are less divergent (located within the P3, CI, and $\mathrm{NIb}$ proteins, and in the $\mathrm{N}$ terminus of the $\mathrm{CP}$ ) rather than to a uniform difference in divergence rates. Notably, the usually hypervariable $\mathrm{N}$ terminus of the CPs of LMV-AF199 and LMV-0 (representatives of LMV-Most and LMV-Common, respectively) differed by only 1 out of 39 amino acid positions, whereas there were 6 differences between LMV-E and LMV-AF199 (Fig. 3). In addition, the homology pattern within the $\mathrm{P} 1$ protein region differs between LMV-0 and LMV-E, with a broad peak in the central region of the P1 domain for the former isolate and two distinct peaks at each end of this domain for the latter (Fig. 4).

\section{DISCUSSION}

The data presented here extends our current knowledge of the molecular clustering of LMV isolates, revealed by the hypervariable NIb-CP junction $(21,23,28)$, in relation to their ability to overcome the resistance afforded by $m o l^{1}$ and $m o l^{2}$ and to be seedborne. Because the present molecular analysis is based on a single genomic region possibly not directly related to these biological properties, it cannot be excluded that these molecular and biological properties can segregate in recombinant isolates. However, a previous analysis of a more limited set of isolates suggested that intraspecific recombination was not frequent in LMV, and that a single region was therefore adequate to describe the clustering of LMV isolates (21).

Sequence-based clusterings of LMV isolates were consistent when three different algorithmic approaches (neighbor joining, maximum likelihood, and parsimony) were used, and did not reveal new branches in the dendrograms beyond the three major clusters previously identified (LMV-Yar, LMV-Greek, and LMVRoW) (21). No new member of the Yar cluster was identified, and this branch still contains a single, molecularly divergent isolate, LMV-Yar (19,21). Seven additional isolates from Greece were placed into the Greek cluster. However, some isolates from lettuce, ornamentals, or weeds, harvested in 1999 and 2000 in Greece, either from Athens or Crete, were placed in the RoW cluster. LMV-RoW was previously named LMV-WE-C based upon the Western European and Californian origin of the isolates known at this time (22), but it was renamed because it now includes isolates from all parts of the world represented in this analysis (West Africa, North Africa, North America, South America, East Asia, Australia, and Europe). Recently, we characterized an additional isolate from Israel (Middle East) and found it also was a member of LMV-RoW (data not shown).

The coexistence in Greece of isolates belonging to the endemic Greek cluster and to the RoW cluster may have resulted from the recent introduction of the latter, perhaps through commercial exchange of contaminated lettuce seed or of other hosts of LMV. Alternatively, these two types of isolates may have coexisted in Greece but within distinct ecological niches (natural reservoirs and time of yearly appearance, etc.). The isolates within the Greek cluster usually induce severe symptoms $(16,21)$ and overcome the

TABLE 2. Intraspecific and interspecific average genetic distances in the genomic region considered in this study ${ }^{\mathrm{a}}$

\begin{tabular}{|c|c|c|c|c|c|}
\hline Virus & Plum pox virus (PPV) & $\begin{array}{c}\text { Pea seed-borne mosaic } \\
\text { virus (PSbMV) }\end{array}$ & $\begin{array}{c}\text { Papaya ringspot virus } \\
\text { (PRSV) }\end{array}$ & Potato virus $Y$ (PVY) & $\begin{array}{c}\text { Lettuce mosaic virus } \\
\text { (LMV) }\end{array}$ \\
\hline LMV & $2.272 \pm 0.247$ & $2.401 \pm 0.160$ & $1.606 \pm 0.220$ & $1.154 \pm 0.089$ & $0.250 \pm 0.113$ \\
\hline PVY & $4.845 \pm 0.778$ & $2.788 \pm 0.383$ & $1.300 \pm 0.114$ & $0.202 \pm 0.077$ & $\ldots$ \\
\hline PSbMV & $3.199 \pm 0.371$ & $0.171 \pm 0.087$ & $\ldots$ & $\ldots$ & $\ldots$ \\
\hline PPV & $0.479 \pm 0.206$ & $\ldots$ & $\cdots$ & $\ldots$ & $\ldots$ \\
\hline
\end{tabular}

a The distances are expressed in substitutions per site according to Kimura's parameters (14). Intraspecific distances were evaluated using a set of five isolates representative of the major lineages for each virus. For LMV, the isolates used were Yar, Gr5, E, AF199, and 0. 
resistance afforded by the $m o l^{1}$ or $m o l^{2}$ genes but are not seedborne, providing a potential explanation for their apparent geographical restriction to Greece.

Within the RoW cluster, eight dendrogram branches (nine including LMV-Romaine) were distinguished. Most RoW branches were represented by one or few isolates, with various resistancebreaking capabilities and symptom types (data not shown) $(21,34)$. However, two larger RoW groups could be correlated with biological properties, LMV-Common and LMV-Most. LMVCommon isolates are unable to overcome either $m o l^{1}$ or $m o l^{2}$, whereas LMV-Most isolates combine seed transmission and the ability to overcome both $m o l^{1}$ and $\mathrm{mol}^{2}$. Given their respective positions in the dendrograms derived from the hypervariable sequence at the NIb-CP junction, LMV-Most and LMV-Common probably evolved from a common ancestor rather than one being directly derived from the other.

The origin of LMV in lettuce crops may be of three alternative, but not exclusive, types: from contaminated seeds (31), from weed reservoirs (36), or from ornamental plants (35). Isolates that are not seedborne in lettuce would only originate from weeds or ornamentals, whereas seedborne isolates have an additional means of introduction into lettuce fields. In addition, contaminated seeds may facilitate survival during winter or lettuce-free periods. The repeated recovery from various countries of closely related isolates belonging to either of the two only seedborne groups (LMVCommon or LMV-Most) indeed points to the key role of seed transmission in the worldwide epidemiological success of a given isolate.

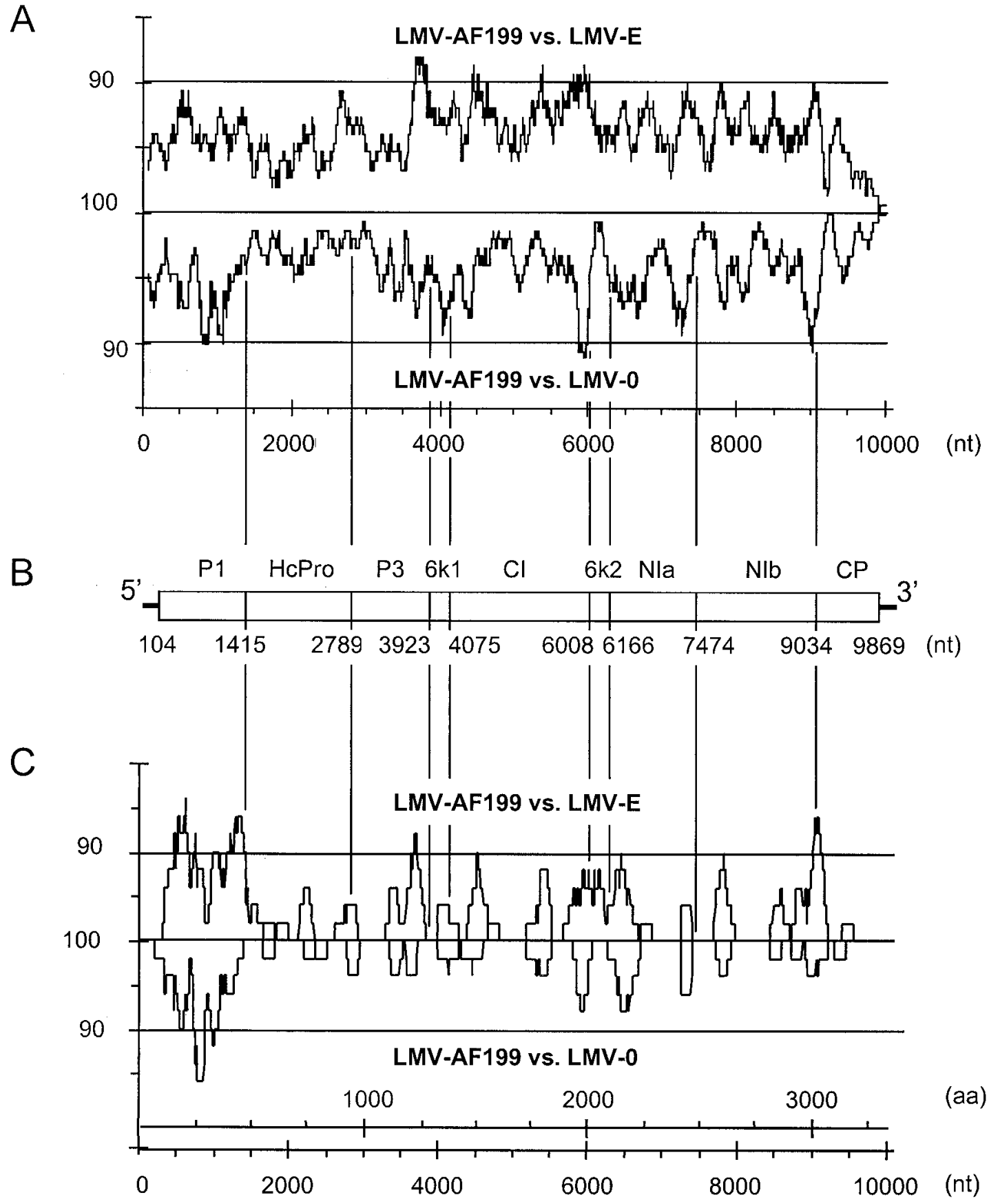

Fig. 4. Percent sequence identities between Lettuce mosaic virus (LMV)-AF-199 and LMV-E or LMV-0 along their genomes. The percent identity between LMV-AF199 and LMV-E (upper curves) and LMV-AF199 and LMV-0 (lower curves) measured in a window of A, 150 nucleotides or C, 50 amino acids was plotted at each position. B, The genetic map of LMV is shown, with the identity of the cleavage products and the positions of the polyprotein cleavage sites numbered in relation to the nucleotide sequence. 
The complete genomic sequence of LMV-AF199 was determined in an attempt to further characterize LMV-Most. This provided a direct comparison among LMV isolates belonging to three branches within LMV-RoW. The level of nucleotide divergence in relation to LMV-0 (a seedborne, non-resistancebreaking LMV-Common isolate) and LMV-E (a non-seedborne, resistance-breaking isolate within the RoW cluster but outside LMV-Common and LMV-Most) suggests that recombination has not recently taken place in the history of these three isolates. The level of sequence conservation is very high between LMVAF199 and both reference isolates, especially LMV-0 in which only 65 amino acids ( 27 in the P1 coding region alone) out of 3,255 (2\%) differed.

Although no molecular clock is available, the limited sequence variability observed within LMV-Most isolates compared with LMV-Common isolates is probably an indication that the latter has had a longer worldwide epidemiological history than the former. In other words, LMV-Most may have emerged in lettuce crops more recently than LMV-Common. This is in agreement with the relatively recent description of the first isolate of this type, LMV-13 (8). However, identification of LMV-Most from various regions of the world, including South America, Europe, and North Africa, indicates that these isolates have already spread to a number of geographically separated lettuce growing areas, most likely through contaminated seed lots. Surprisingly, LMVMost was never found in seed lots of susceptible lettuce cultivars (Table 1), and few LMV-Most isolates were found in susceptible lettuce cultivars in the field, suggesting the possibility that LMVMost suffers some lack of fitness in the absence of selection pressure.

LMV-Most combines resistance-breaking and seed-transmissibility, and is thus a potential threat to lettuce production. It took less than 10 years after its original isolation to attain worldwide prevalence. Relationships among LMV isolates suggested that emergence of LMV-Most is not the result of multiple convergent evolution events but rather of the efficient spread, probably through exchange of contaminated seeds, of a resistance-breaking isolate initially present in one particular geographical location.

\section{ACKNOWLEDGMENTS}

This work was partially supported by French-Tunisian (CMCU 99/FO913), French-Greek (Platon 99.080), and French-Brazilian (CAPESCOFECUB 255/98 and 342/01) bilateral exchanges, and by the Conseil Régional d'Aquitaine. R. Krause-Sakate was financially supported by a grant from the Brazilian Coordenação de Aperfeiçoamento de Pessoal de Nível Superior (CAPES). We thank A. Aboulata, H. Huet, B. Maisonneuve, J. Thomas, and T. Wetzel for providing LMV isolates, and E. Ryder for providing the early flowering lettuce line $8720 \mathrm{M}$. Contaminated seed batches were analyzed within the context of a Contrat de Branche granted by the French Ministry of Agriculture and involving seven seed companies under an anonymity agreement.

\section{LITERATURE CITED}

1. Atreya, P. L., Atreya, C. D., and Pirone, T. P. 1991. Amino acid substitutions in the coat protein result in loss of insect transmissibility of a plant virus. Proc. Natl. Acad. Sci. USA 88:7887-7897.

2. Bannerot, H., Boulidard, L., Marrou, J., and Duteil, M. 1969. Etude de l'hérédité de la tolérance au virus de la mosaïque de la laitue chez la variété Gallega de Invierno. Etud. Virol. Ann. Phytopathol. 1:219-226.

3. Barnett, O. W., Adam, G., Brunt, A. A., Dijkstra, J., Dougherty, W. G., Edwardson, J. R., Goldbach, R., Hammond, J., Hill, J. H., Jordan, R. L., Kashiwazaki, S., Lommel, S. A., Makkouk, K., Morales, F. J., Ohki, S. T., Purcifull, D., Shikata, E., Shukla, D. D., and Uyeda, I. 1995. Family Potyviridae. Pages 348-358 in: Virus Taxonomy. Sixth Report of the International Committee on Taxonomy of Viruses. F. A. Murphy, C. M. Fauquet, D. H. L. Bishop, S. A. Ghabrial, A. W. Jarvis, G. P. Martelli, M. A. Mayo, and M. D. Summers, eds. Springer-Verlag, Wien.

4. Bertheau, Y., Frechon, D., Toth, I. K., and Hyman, L. J. 1998. Methods for the Detection and Quantification of Erwinia carotovora subsp. atroseptica on Potatoes. M. C. M. Perombelon and J. M. van der Wolff, eds. Scott. Crop Res. Inst. Occas. Publ., Dundee.

5. Bos, L. 1977. Persistence of infectivity of three viruses in plant material dried over $\mathrm{CaCl}_{2}$ and stored under different conditions. Neth. J. Plant Pathol. 83:217-220.

6. Cervera, M. T., Riechmann, J. L., Martin, M. T., and Garcia, J. A. 1993. 3'-Terminal sequence of the plum pox virus PS and o6 isolates: Evidence for RNA recombination within the potyvirus group. J. Gen. Virol. 74:329-334.

7. Clark, M. F., and Adams, A. N. 1977. Characteristics of the microplate method of enzyme-linked immunosorbent assay for the detection of plant viruses. J. Gen. Virol. 34:475-483.

8. Dinant, S., and Lot, H. 1992. Lettuce mosaic virus: A review. Plant Pathol. 41:528-542.

9. Falk, B. W., and Purcifull, D. E. 1983. Development and application of an enzyme-linked immunosorbent assay (ELISA) test to index lettuce seeds for lettuce mosaic virus in Florida. Plant Dis. 67:413-416.

10. Felsenstein, J. 1981. Evolutionary trees from DNA sequences: A maximum likelihood approach. J. Mol. Evol. 17:368-376.

11. Felsenstein, J. 1983. Parsimony in systematics: Biological and statistical issues. Annu. Rev. Ecol. Syst. 14:313-333.

12. Felsenstein, J. 1985. Confidence limits on phylogenies: An approach using the bootstrap. Evolution 39:783-791.

13. Jeanmougin, F., Thompson, J. D., Gouy, M., Higgins, D. G., and Gibson, T. J. 1998. Multiple sequence alignment with Clustal X. Trends Biochem. Sci. 23:403-405.

14. Kimura, M. 1980. A simple method for estimating evolutionary rate of base substitutions through comparative studies of nucleotide sequences. J. Mol. Evol. 16:111-120.

15. Krause-Sakate, R., Mello, R. N., Maciel-Zambolim, E., Pavan, M. A., Carvalho, M. G., Le Gall, O., and Zerbini, F. M. 2001. Molecular characterization of two Brazilian isolates of Lettuce mosaic virus (LMV), with distinct biological properties. Fitopatol. Bras. 26:153-157.

16. Kyriakopoulou, P. 1985. A lethal strain of Lettuce mosaic virus in Greece. Phytoparasitica 13:271.

17. Le Gall, O., Lanneau, M., Candresse, T., and Dunez, J. 1995. The nucleotide sequence of the RNA-2 of an isolate from the English serotype of tomato black ring nepovirus: RNA recombination in the history of nepoviruses. J. Gen. Virol. 76:1279-1283.

18. Page, R. D. M. 1996. TREEVIEW: An application to display phylogenetic trees on personal computers. Comput. Appl. Biosci. 12:357358.

19. Pink, D. A. C., Kostova, D., and Walkey, D. G. A. 1992. Differentiation of pathotypes of lettuce mosaic virus. Plant Pathol. 41:5-12.

20. Pink, D. A. C., Lot, H., and Johnson, R. 1992. Novel pathotypes of lettuce mosaic virus-Breakdown of a durable resistance? Euphytica 63:169-174.

21. Revers, F., Lot, H., Souche, S., Le Gall, O., Candresse, T., and Dunez, J. 1997. Biological and molecular variability of lettuce mosaic virus isolates. Phytopathology 87:397-403.

22. Revers, F., van der Vlugt, R. A. A., Souche, S., Lanneau, M., Lot, H., Candresse, T., and Le Gall, O. 1999. Nucleotide sequence of the 3' terminal region of the genome of four Lettuce mosaic virus isolates from Greece and Yemen. Arch. Virol. 144:1619-1626.

23. Revers, F., Yang, S. J., Walter, J., Souche, S., Lot, H., Le Gall, O., Candresse, T., and Dunez, J. 1997. Comparison of the complete nucleotide sequences of two isolates of Lettuce mosaic virus differing in their biological properties. Virus Res. 47:167-177.

24. Ryder, E. J. 1970. Inheritance of resistance to common lettuce mosaic. J. Am. Soc. Hortic. Sci. 95:378-379.

25. Ryder, E. J. 1973. Seed transmission of LMV in mosaic resistant lettuce. J. Am. Soc. Hortic. Sci. 98:610-614.

26. Saitou, N., and Nei, M. 1987. The neighbor-joining method: A new method for reconstructing phylogenetic trees. Mol. Biol. Evol. 4:406425.

27. Sawyer, S. 1989. Apply statistical tests for apparent gene conversion for aligned DNA or protein sequence data. Mol. Biol. Evol. 6:526-538.

28. Shukla, D. D., Ward, C. W., and Brunt, A. A. 1994. The Potyviridae. CAB International, Wallingford, UK.

29. Stangarlin, O., Pavan, M. A., and da Silva, N. 2000. Occurrence of a new pathotype of Lettuce mosaic virus on lettuce in Brazil. Plant Dis. $84: 490$.

30. Thompson, J. D., Higgins, D. G., and Gibson, T. J. 1994. CLUSTAL W: Improving the sensitivity of progressive multiple sequence alignment through sequence weighting, positions-specific gap penalties and weight matrix choice. Nucleic Acids Res. 22:4673-4680.

31. Tomlinson, J. A. 1962. Control of lettuce mosaic by the use of healthy seed. Plant Pathol. 11:61-64.

32. van Vuurde, J. W. L., and Maat, D. Z. 1983. Routine application of 
ELISA for the detection of lettuce mosaic virus in lettuce seeds. Seed Sci. Technol. 11:505-508.

33. Walkey, D. G. A., Ward, C. M., and Phelps, K. 1985. Studies on lettuce mosaic virus resistance in commercial lettuce cultivars. Plant Pathol. 34:545-551.

34. Zerbini, F. M., Koike, S. T., and Gilbertson, R. L. 1995. Biological and molecular characterization of lettuce mosaic potyvirus isolates from the Salinas Valley of California. Phytopathology 85:746-752.
35. Zerbini, F. M., Koike, S. T., and Gilbertson, R. L. 1997. Gazania spp.: A new host of lettuce mosaic potyvirus, and a potential inoculum source for recent lettuce mosaic outbreaks in the Salinas Valley of California. Plant Dis. 81:641-646.

36. Zink, F. W., Duffus, J. E., and Kimble, K. A. 1973. Relationships of a non-lethal reaction to a virulent isolate of lettuce mosaic virus and turnip mosaic susceptibility in lettuce. J. Am. Soc. Hortic. Sci. 98: $41-45$. 